\title{
Bacterial Communities of Drosophila suzukii (Matsumura, 1931) (Diptera: Drosophilidae) Damaged in Strawberry in Turkey ${ }^{i}$
}

\author{
Elif Tozlư ${ }^{1, *}$, Nasibe Tekiner ${ }^{1}$, Göksel Tozlu ${ }^{1}, \operatorname{Recep~Kotan}^{1}$, Hatice Öğütçü ${ }^{2}$ \\ ${ }^{1}$ Plant Protection Department, Agricultural Faculty, Ataturk University, Erzurum, Turkey \\ ${ }^{2}$ Field Crop Department, Agricultural Faculty, Ahi Evran University, Kırşehir, Turkey
}

Copyright $\bigcirc 2018$ by authors, all rights reserved. Authors agree that this article remains permanently open access under the terms of the Creative Commons Attribution License 4.0 International License

\begin{abstract}
Drosophila suzukii (Matsumura, 1931) (Diptera: Drosophilidae) is an invasive species originating from Southeastern Asia and spreads in a fast manner. It is among major threats in soft-shell fruit cultivation in the whole world. It was detected in 2014 in Turkey. According to international criteria, it is considered that it has the potential of threatening the fruit cultivation in Turkey where garden plants are grown widely. In this study, a total of 39 bacterial strains were isolated from 100 mature
\end{abstract} Drosophila suzukii individuals. Gram staining characteristics, catalase, oxidase and nitrate reductase activities and chitinase enzyme activities and hypersensitivity reaction of these strains were determined by using microscopical and visual inspection. The bacterial strains were identified according to their fatty acid methyl esters (FAME) analysis by using Sherlock Microbial Identification System (MIS). The identification test results of the bacterial strains were also confirmed by phylogenetic analysis and their closely related species based on the 16S rRNA sequence. The most abundant bacterial species were Paenibacillus alvei $(31.57 \%)$ and Bacillus amyloliquefaciens (47.36\%) according to the MIS and 16S rRNA sequence analysis results, respectively. According to the MIS results, a total of 6 strains identified as Paenibacillus alvei were identified as Bacillus amyloliquefaciens according to the $16 \mathrm{~S}$ rRNA sequence analysis results. A total of three Paenibacillus macerans strains identified in MIS system were also identified as Bacillus amyloliquefaciens according to the 16S rRNA sequence analysis. Morphological and biochemical characteristics results of all of Bacillus amyloliquefaciens strains showed the some results. According to the $16 \mathrm{~S}$ rRNA sequence analysis results, the other bacterial strains consist of 1 Bacillus atrophaeus (5.2\%), 1 Bacillus safensis (5.2\%), 1 Paenibacillus motobuensis (5.2\%) and 1 Staphylococcus epidermidis (5.2\%) strains. To our knowledge, this is the first study characterizing the bacterial communities of Drosophila suzukii.

Keywords Bacteria, Biological Control, Drosophila suzukii, Microbiota

\section{Introduction}

Drosophila suzukii (Matsumura, 1931) (Diptera: Drosophilidae), an indigenous species to the continent of Asia, was first reported outside this continent in 1980 in Hawaiian Islands of the North America [1]. Within two years, it completely invaded the northern parts of Continent of America from west to the east, and consequently reached Canada at north and Mexico at south [2-5]. In the field study in which European Drosophilidae species were recorded, D. suzukii emerged as a predominant Drosophilidae species in the highlands where it habitates. From this date on, the first records in Italy [6], France [7], Switzerland [8], Slovenia [9], Croatia [10], Austria [11], United Kingdom, Portugal [12], Germany [13], Belgium [14], Hungary [15], Serbia [16], Bosnia and Herzegovina [17], Bulgaria [18], Greece (Crete Island) [19], Poland [20] and Japan [21] were reported. The first record in Turkey was in Erzurum in August-September 2014 [22].

Although the primary hosts of $D$. suzukii are cherry, sour cherry, strawberries, blackberries, raspberries and blueberries, a very wide spectrum of fruits can be affected. It can cause also serious damage to fruits such as fig, apricot, peach, plum, grape, medlar, greenhouse mandarin, kiwi, persimmon, and fallen or cracked apple and orange [2, $4,23,24]$. It is estimated that these losses have affected $14 \%$ of all potential fruit production worldwide [25].

Due to the wide range of host fruit selection and rapid spreading, it is stated that this species is an important pest that is likely to cause major losses to the European and 
American fruit industry in the near future [3-4].

While other Drosophila species feed on rotten fruits, $D$. suzukii prefers newly ripening fruits on the tree, and using their saw-shaped ovipositor, female individuals lay their eggs inside the fruits prior to their maturation for harvesting, which all make this organism a very important agricultural pest [2]. While the larvae feed on the rich protein content of the flesh of the fruit, the synthesis of inherent ethylene is increased in areas where tissue integrity is compromised. Ethylene synthesis locally accelerates maturity and causes collapse/softening (rotting) of the flesh of the fruit. As a result, these products lose their market value within a short period of time. In addition, the wounds that these flies open on the fruit for laying their eggs lead to additional losses caused by pathogens, including fungi and bacteria [26].

Few studies have been carried out to identify the microflora of this pest. The first study that was conducted to identify the bacterial flora of $D$. suzukii revealed species belonging to the genera Gluconobacter and Acetobacter [27]. Another study reported that Wolbachia spp.
(Rickettsiales: Rickettsiaceae) could be used in biological control of this pest [28-29]. To our knowledge, there is not any study characterizing the microbial communities of $D$. suzukii.

The present study aims to determine the microflora of D. suzukii which continues to spread rapidly and cause economic losses.

\section{Materials and Methods}

\subsection{Pest Samples}

The study was conducted on 100 healthy adult $D$. suzukii individuals collected on July 25th-26th, 2016 in Erzurum province of Turkey using traps prepared with cider vinegar (Figure 1) in strawberry trial fields where neither insecticide nor fungicide was used. Collected adult individuals were put into tubes and brought to Atatürk University Plant Protection Department, Plant Clinical Laboratory.

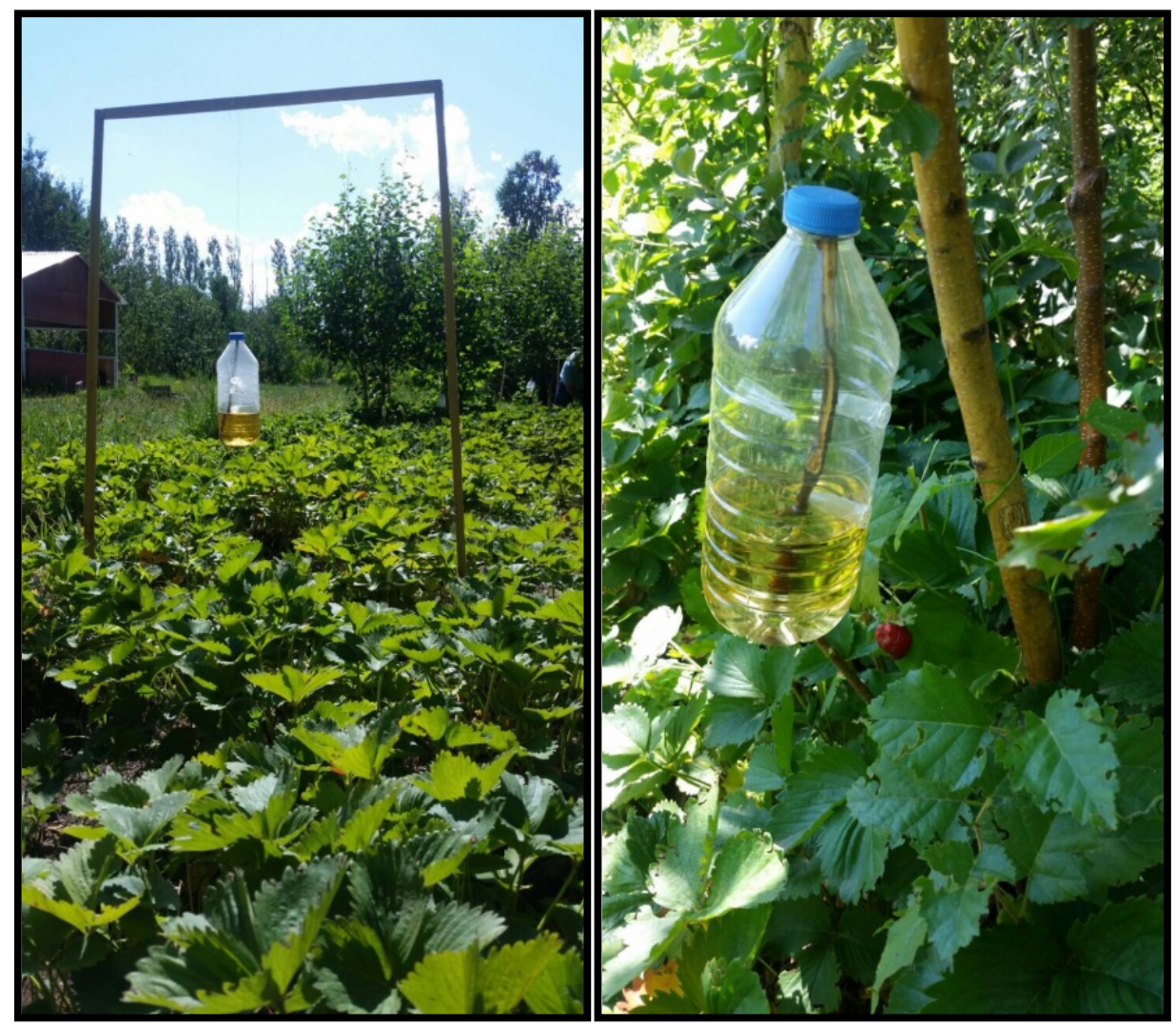

Figure 1. The traps used for Drosophila suzukii 


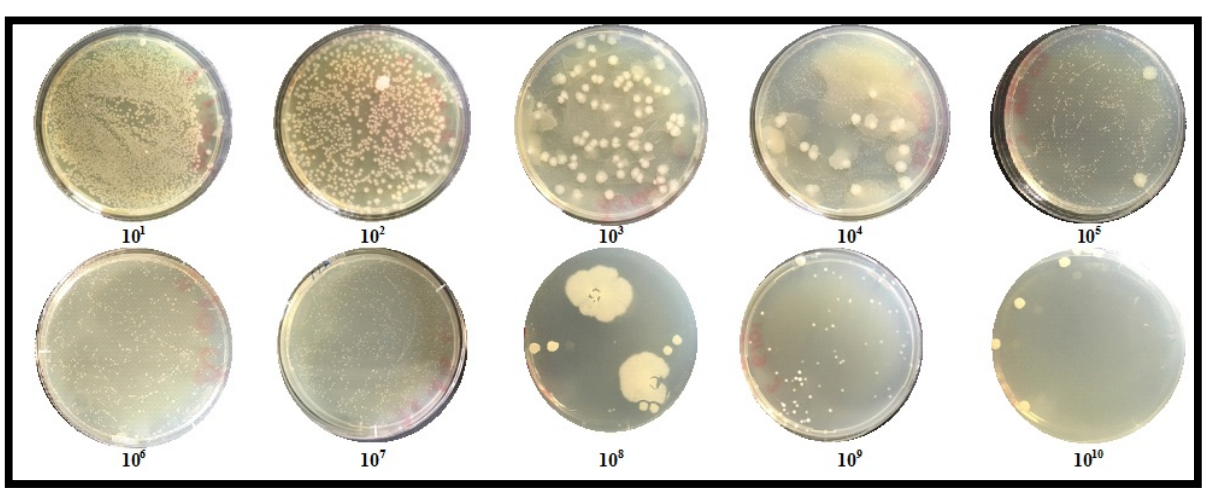

Figure 2. Serial dilutions were obtained from Drosophila suzukii adults

\subsection{Isolation of Bacterial Strains}

Superficial sterilization was applied to $D$. suzukii adults in tens with $95 \%$ ethyl alcohol for 5 minutes. Adults were homogenized by pulverizing in a sterile mortar with sterile saline solution and serial dilutions were obtained from this homogenate [30] (Figure 2). The dilutions prepared from the adults were inoculated on Nutrient Agar (NA) for bacterial growth. Then, Bacterial cultures were incubated at $30^{\circ} \mathrm{C}$, and at the end of $24-72$ hours. The bacterial strains with the dominant character were selected and purified [31]. Each of single colonies was prufied and streaked on agar plate. For each pure culture was given a separate code number, and information regarding the isolation conditions (location, altitude, insect form, date, etc.) was noted. The samples were kept at $-86^{\circ} \mathrm{C}$ in stock growth media containing 30\% glycerol and Loria Broth (LB) for routine use.

\subsection{Determination of Morphological and Biochemical Properties of Bacterial Strains}

The colony morphology and color of the bacterial strains were determined microscopical and visual inspection.

The Gram staining characteristics of the bacteria were determined according to the method described by Sands [32]. Presence of catalase and oxidase enzymes [33] and nitrate enzyme was assessed by the method of Harley and Prescott [34]. Chitinase enzyme activity was determined according to the method reported by Ortucu [35].

\subsection{Polymerase Chain Reaction (PCR) of the Bacterial Strains}

The strains were also identified in the molecular system. Total 19 bacterial strains selected from 39 bacterial strains obtained from $D$. suzukii adults according to high colony density were identified by sequencing a fragment of genome [36]. Bacterial DNA was amplified by a two-step PCR targeting the $16 \mathrm{~S}$ rDNA gene with primers $27 \mathrm{~F}$ and 907R, designed to include Illumina adaptor and barcode sequences. Sequencing was performed on an
IlluminaMiSeq at the UC Davis Genomics Core Facility generating 963 basepair paired-end reads. Samples were OTUs are identified by their closest hit in the SILVA SSU Reference Database Release 111. Number of sequences is after all quality-control steps.

\subsection{Phylogenetic Relationship of the Bacterial Strains}

The sequences obtained were used to perform BLAST searches using the NCBI GenBank database to confirm strain identification Altschul et al. [37]. Evolutionary relationships of the 19 bacterial strains were evaluated. Cluster analyses of the sequences were performed using BioEdit (version 7.09) with Clustal W followed by neighbor joining analysis on aligned sequences performed with MEGA 6.0 software [38] Reliability of dendograms was tested by bootstrap analysis with 1000 replicates using MEGA 6.0.

The evolutionary history was inferred using the Neighbor-Joining method [39]. The optimal tree with the sum of branch length $=0.56341095$ is shown. The percentage of replicate trees in which the associated taxa clustered together in the bootstrap test (1000 replicates) is shown next to the branches [40]. The tree is drawn to scale, with branch lengths in the same units as those of the evolutionary distances used to infer the phylogenetic tree. The evolutionary distances were computed using the Maximum Composite Likelihood method [41] and are in the units of the number of base substitutions per site. The analysis involved 16 nucleotide sequences. Codon positions included were $1 \mathrm{st}+2 \mathrm{nd}+3 \mathrm{rd}+$ Noncoding. All positions containing gaps and missing data were eliminated. There were a total of 823 positions in the final dataset. Evolutionary analyses were conducted [38].

\section{Results}

The identification test results of the isolated bacteria and their morphological and biochemical characteristics were given in Table 1. 
Table 1. Identification test results of the isolated bacteria and their morphological and biochemical characteristics test results

\begin{tabular}{|c|c|c|c|c|c|c|c|c|c|}
\hline Strains & BLAST top hit & $\begin{array}{c}\text { Identify } \\
(\%)\end{array}$ & $\begin{array}{l}\text { Colony } \\
\text { shape }\end{array}$ & $\begin{array}{l}\text { Colony } \\
\text { color }\end{array}$ & $\begin{array}{c}\text { Gram } \\
\text { staining }\end{array}$ & $\begin{array}{c}\text { Catalase } \\
\text { test }\end{array}$ & $\begin{array}{c}\text { Oxidase } \\
\text { test }\end{array}$ & $\begin{array}{c}\text { Nitrate } \\
\text { reduction }\end{array}$ & $\begin{array}{l}\text { Chitinase } \\
\text { activity }\end{array}$ \\
\hline RK 1792 & $\begin{array}{c}\text { Bacillus } \\
\text { amyloliquefaciens }\end{array}$ & 99 & $\operatorname{rod}$ & cream & + & + & + & + & - \\
\hline RK 1801 & $\begin{array}{c}\text { Bacillus } \\
\text { amyloliquefaciens }\end{array}$ & 99 & $\operatorname{rod}$ & cream & + & + & + & + & - \\
\hline RK 1805 & $\begin{array}{c}\text { Bacillus } \\
\text { amyloliquefaciens }\end{array}$ & 99 & rod & cream & + & + & + & + & - \\
\hline RK 1809 & $\begin{array}{c}\text { Bacillus } \\
\text { amyloliquefaciens }\end{array}$ & 99 & $\operatorname{rod}$ & cream & + & + & + & + & - \\
\hline RK 1810 & $\begin{array}{c}\text { Bacillus } \\
\text { amyloliquefaciens }\end{array}$ & 98 & $\operatorname{rod}$ & cream & + & + & + & + & - \\
\hline RK 1812 & $\begin{array}{c}\text { Bacillus } \\
\text { amyloliquefaciens }\end{array}$ & 99 & rod & cream & + & + & + & + & - \\
\hline RK 1813 & $\begin{array}{c}\text { Bacillus } \\
\text { amyloliquefaciens }\end{array}$ & 99 & $\operatorname{rod}$ & cream & + & + & + & + & - \\
\hline RK 1814 & $\begin{array}{c}\text { Bacillus } \\
\text { amyloliquefaciens }\end{array}$ & 99 & $\operatorname{rod}$ & cream & + & + & + & + & - \\
\hline RK 1815 & $\begin{array}{c}\text { Bacillus } \\
\text { amyloliquefaciens }\end{array}$ & 99 & $\operatorname{rod}$ & cream & + & + & + & + & - \\
\hline RK 1811 & Bacillus atrophaeus & 99 & $\operatorname{rod}$ & cream & + & + & - & + & + \\
\hline RK 1807 & Bacillus safensis & 93 & rod & cream & + & + & + & - & - \\
\hline RK 1770 & $\begin{array}{c}\text { Paenibacillus } \\
\text { motobuensis }\end{array}$ & 99 & $\operatorname{rod}$ & white & - & + & + & + & + \\
\hline RK 1784 & Proteus myxofaciens & 99 & $\operatorname{rod}$ & cream & - & + & - & + & - \\
\hline RK 1785 & Proteus myxofaciens & 99 & $\operatorname{rod}$ & Cream & - & + & - & + & - \\
\hline RK 1787 & Proteus myxofaciens & 99 & $\operatorname{rod}$ & cream & - & + & - & + & - \\
\hline RK 1768 & $\begin{array}{l}\text { Staphylococcus } \\
\text { epidermidis }\end{array}$ & 99 & cocci & white & + & + & - & + & - \\
\hline RK 1765 & nd & - & $\operatorname{rod}$ & cream & - & + & + & + & - \\
\hline RK 1767 & nd & - & $\operatorname{rod}$ & cream & - & + & - & - & - \\
\hline RK 1769 & nd & - & rod & cream & - & + & - & - & - \\
\hline \multicolumn{3}{|c|}{ Other a total of 12 bacterial strains } & $\mathrm{nt}$ & nt & $\mathrm{nt}$ & $\mathrm{nt}$ & $\mathrm{nt}$ & $\mathrm{nt}$ & nt \\
\hline \multicolumn{3}{|c|}{ Undefined a total of 8 bacterial strains } & $\mathrm{nt}$ & $\mathrm{nt}$ & $\mathrm{nt}$ & $\mathrm{nt}$ & $\mathrm{nt}$ & $\mathrm{nt}$ & $\mathrm{nt}$ \\
\hline
\end{tabular}

SIM: Similarity index, nd: Not determined; +: Positive reaction, -: Negative reaction, nt: Not tested

It was observed that the RK 1768 strain had a rod shaped colony, whereas other strains had a rounded colony shape, and that RK 1768 and RK 1770 strains had a white colony color while the other strains had cream colony color (Table 1). The strains RK 1770, RK 1784, RK 1785 and RK 1787 were gram-negative, while other strains were gram-positive. All strains had positive catalase and nitrate test results. Except RK 1770 and RK 1811 all other strains had negative chitinase test results. Chitinase activity of RK-1811 and RK-1770 strains was positive (Table 1) (Figure 3).

The bacterial strains with high colony density that were obtained from $D$. suzukii adults were identified molecular analysis. Molecular diagnostic results are given in Table 1. According to the 16S rRNA sequence analysis results, a total of 9 strains were identified as Bacillus amyloliquefaciens. The other bacterial strains consist of 3 Proteus myxofaciens, 1 Bacillus atrophaeus, 1 Bacillus safensis, 1 Paenibacillus motobuensis and 1 Staphylococcus epidermidis. Percent identify of all the identified bacterial strains were $99 \%$. But, a total of three strains were not identified (Table 1).

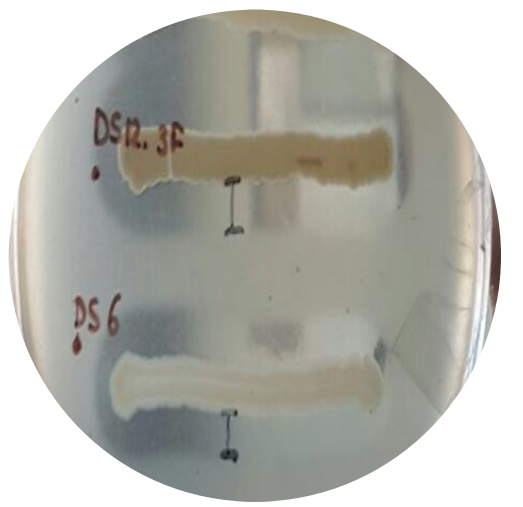

Figure 3. Chitinase positive bacterial strains 


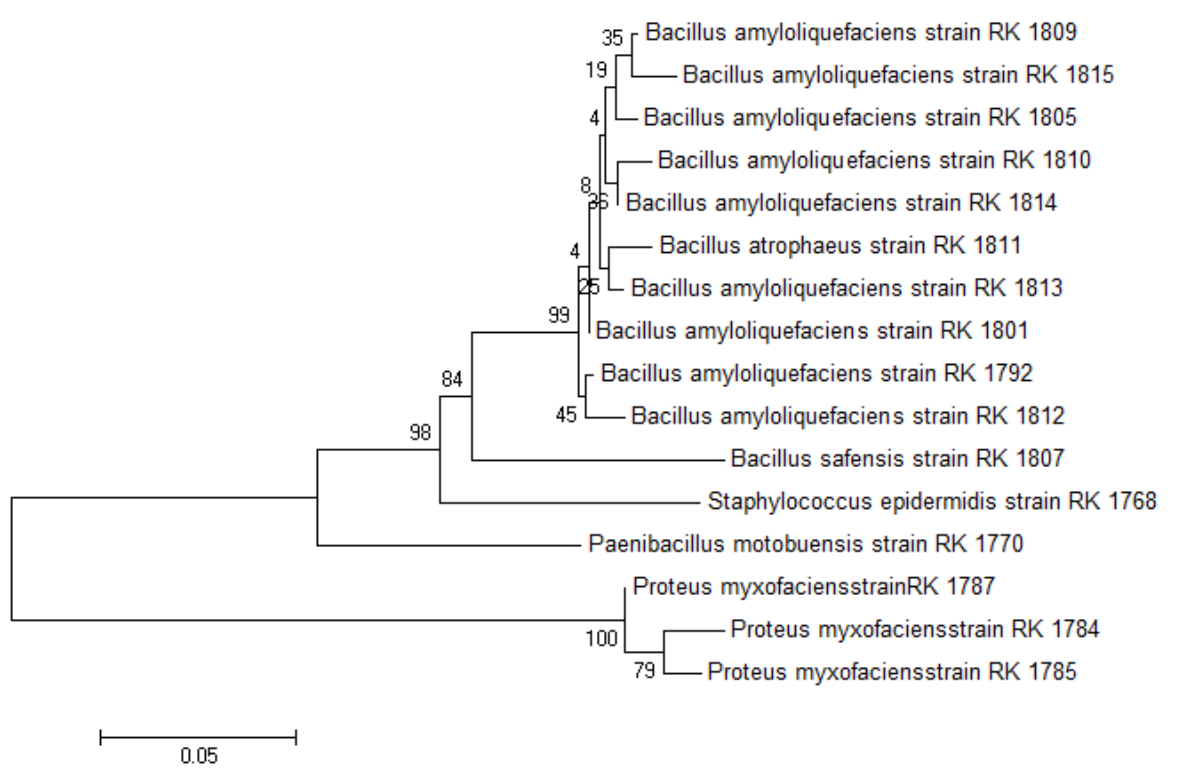

Figure 4. Evolutionary relationships of taxa

These identifications were also confirmed by phylogenetic analysis of the bacterial strains and their closely related species based on the $16 \mathrm{~S}$ rRNA sequence (Figure 4).

\section{Discussion}

Chandler et al. [27], in their microbiota study on $D$. suzukii, isolated the genus Tatumella from $99 \%$ of both the adults and the larvae and Dunitz et al. [42] isolated Tatumella sp. from the larvae. Although this genus is not commonly found in Drosophila species, another study identified it also in D. melanogaster, which feeds on apples [43]. Again, Chandler et al. [27] reported that Acetobacteraceae and Orbus species were also associated with Drosophila population. However, Broderick and Lemaitre [43] noted that Orbus species were not associated with Drosophila. Brummel et al. [44] conducted molecular analyses on strains from the whole body of $D$. melanogaster adults, and they identified the genera Lactobacillus, Gluconabacter, Enterobacter, Anaerococcus, while Cox and Gilmore [45] identified Wolbachia sp., Acetobacter aceti, A. cerevisiae, A. pasteurianus, A. pomorum, Gluconobacter cerinus, Enterobacter cloacae, Klebsiella oxytoca, Lactobacillus plantarum, Leuconostoc mersenteroide and Enterococcus faecalis species.

In this study, the most abundant bacterial species in mature $D$. suzukii individuals were $B$. amyloliquefaciens (47.36\%), Proteus myxofaciens (15.78\%), B. safensis, $P$. motubensis, S. epidermis (\%5.26) according to the $16 \mathrm{~S}$ rRNA sequence analysis results. This identification results were supported with classical systems in this study. Morphological and biochemical characteristics tests results of all of B. amyloliquefaciens strains showed the some results. According to the $16 \mathrm{~S}$ rRNA sequence analysis results.

It suggests that differences in species distribution in microbial flora studies of the same insect species may be due to the differences in the body part where strains were obtained, the biological period of the pest, and dietary differences. Indeed, it has been stated that, in comparison to isolations made from the whole body, isolations from the gut yielded less microorganisms, that the sample preparation time may also influence variation due to the shorter passage time in the gut [46-47], and that microbiota could differ depending on the variations of consumed food, and whether the individual fed in its natural environment or in laboratory setting [47].

As it can be seen from all these studies, there is ongoing research on microbiota of $D$. suzukii species. It is thought that microbiota studies will guide biological pest control studies. The discovery of new pathogens and parasites of pest insects offers a chance to find organisms that may be useful for biological control [48]. For this purpose it has become increasingly important to identify microorganisms which are present in the microbiota of harmful organisms, and can be used in control of these pests, and to study them in biological control research. Identification of microorganisms that have the potential to be used in biological pest control against the invasive species $D$. suzukii will be possible detailed studies on this subject.

\section{Conclusions}

To our knowledge, this is the first study characterizing the bacterial communities of Drosophila suzukii. In conclusion, we think that expecially Bacillus 
amyloliquefaciens strains can be used as biological control agents against this economically important pest. Biological control studies will be planned with bacterial strains stored in the Atatürk University, Plant Protection Laboratory in future.

\section{Acknowledgments}

We thank to Dr. Serkan ÖRTÜCÜ for helping molecular identification of bacterial strains.

\section{REFERENCE}

[1] K.Y. Kaneshiro. Drosophila (Sophophora) suzukii (Matsumura). Proceeding Hawaiian Entomology Society. Vol. 24, 179, 1983.

[2] D.B. Walsh, M.P. Bolda, R.E. Goodhue, A.J. Dreves, J. Lee, D.J. Bruck, V.M. Walton, S.D. O'neal, F.G. Zalom. Drosophila suzukii (Diptera: Drosophilidae): invasive pest of ripening soft fruit expanding its geographic range and damage potential. J. of Integr. Pest Manage. Vol. 2, No. 1, G1-G7, 2011. http://dx.doi.org/10.1603/IPM10010.

[3] G. Calabria, J. Maca, G. Bachli, L. Serra, M. Pascual. First records of the potential pest species Drosophila suzukii (Diptera: Drosophilidae) in Europe. J. of App. Entomol., Vol. 136, 139-147, 2012. doi: 10.1111/j.1439-0418.2010.0 1583.x.

[4] A. Cini, C. Ioriatti, G. Anfora. A review of the invasion of Drosophila suzukii in Europe and a draft research agenda for integrated pest management. Bull. of Insect., Vol. 65, 149-160, 2012. http://hd1.handle.net/10449/21029.

[5] K.A. Hamby, R.S. Kwok, F.G. Zalom, J.C. Chiu. Integrating circadian activity and gene expression profiles to predict chronotoxicity of Drosophila suzukii response toinsecticides. PLoSONE, Vol. 8, No. 7, e68472, 2013. doi: 10.1007/s10340-016-0768-1.

http://www.plosone.org/article/info\%3Adoi\%2F10.1371\% 2Fjournal.pone.006842. (accessed: 22 January 2016).

[6] A. Grassi, L. Palmieri, L. Giongo. New pests of the small fruits in Trentino (Nuovo fitofago per i piccoli frutti in Trentino). Terra Trentina., Vol. 55, 19-23, 2009.

[7] J.F. Mandrin, C. Weydert, Y Trottin-Caudal. Fruit falls victim to a newly-arrived pest: Drosophila suzukii. First reports of damage to cherry. (Un nouveau ravageur des fruits: Drosophila suzukii. Premiers dégâts observés sur cerises). Infos-Ctifl., Vol. 266, 29-33, 2010.

[8] C. Baroffio, S. Fischer. Neue Bedrohung für Obstplantagen und Beerenpflanzen: die Kirschessigfliege. UFA-Revue., Vol. 11, 46-47, 2011.

[9] G. Seljak. Spotted wing drosophila-Drosophila suzukii (Matsumura). (Plodova vinska musica - Drosophila suzukii (Matsumura). SAD, Revija za Sadjarstvo, Vinogradnistvo in Vinarstvo, Vol. 22, No. 3, 3, 2011. https://www.cabi.org /isc/abstract/20113255279.
[10] T.M. Milek, G. Seljak, M. Simala, M. Bjelis. First record of Drosophila suzukii (Matsumura, 1931) in Croatia. Glasilo Biljne Zastite., Vol. 11, 377-382, 2011.

[11] C. Lethmayer. Gefhrliche fliegen fur Apfel \& Co. Bessers Obst., Vol. 12, 4-5, 2011.

[12] EPPO. First report of Drosophila suzukii in Portugal. EPPO Reporting Service, 10: 4. 2012 https://gd.eppo.int/reporting/article-2415.

[13] H. Vogt, P. Baufeld, J. Gross, K. Kopler, C. Hoffmann. Drosophila suzukii: a new threat feature for the European fruit and viticulture - report for the international conference in Trient, 2, December 2011. Drosophila suzukii: eine neue Bedrohung fur den Europaischen Obst-und Weinbau-Bericht uber eine internationale Tagung in Trient, 2. Dezember 2011. Journal fur Kulturpflanzen., Vol. 64, 68-72, 2012.

[14] J. Mortelmans, H. Casteels, T. Belien. Drosophila suzukii (Diptera: Drosophilidae): a pest species new to Belgium. Belg. J. of Zool., Vol. 142, No. 2,: 143-146, 2012. https://www.researchgate.net/publication/260172928 Dros ophila_suzukii_Diptera_Drosophilidae_A_pest_species_ne W_to_Belgium.

[15] B. Kiss, G. Lengyel, Z. Nagy, Z. Karpati. First record of spotted wing drosophila (Drosophila suzukii Matsumura, 1931) in Hungary. Novenyvedelem., Vol. 49, No. 3, 97-99, 2013.

https://www.cabdirect.org/cabdirect/abstract/20133128433

[16] I. Tosevski, S. Milenkovic, O. Krstic, A. Kosovac, M. Jakovljevic, M. Mitrovic, T. Cvirkovic, J. Jovic. Drosophila suzukii (Matsumura, 1931) (Diptera: Drosophilidae), a new invasive pest in Serbia. Zastita Bilja., Vol. 65, No. 3, 99-101, 2014.

[17] I. Ostojic, M. Zovko, D. Petrovic. First record of spotted wing Drosophila suzukii (Matsumura, 1931) in Bosnia and Herzegovina. Radovi Poljoprivrednog Fakulteta Univerziteta $u$ Sarajevu (Works of the Faculty of Agriculture University of Sarajevo). Vol. 59, 127-133, 2014.

https://www.cabdirect.org/cabdirect/abstract/20143271911

[18] EPPO. First report of Drosophila suzukii in Bulgaria. EPPO Reporting Service, Vol. 1, No. 5, 4361, $2015 \mathrm{a}$. https://gd.eppo.int/reporting/article-4361.

[19] EPPO. First report of Drosophila suzukii in Crete (Greece). EPPO Reporting Service, Vol. 1, No. 5, 4362, 2015 b. https://gd.eppo.int/reporting/article-4362.

[20] EPPO. First report of Drosophila suzukii in Poland. EPPO Reporting Service, Vol. 1, No. 5, 4363, 2015c. https://gd.eppo.int/reporting/article-4363.

[21] H.. Mitsui, M.T. Kimura. Distribution, abundance and host association of two parasitoid species attacking frugivorous Drosophilid larvae in central Japan. Eur. J. of Entomol., Vol. 107, No. 4, 535-540, 2010. doi:10.14411/eje.2010.061.

[22] A. Orhan, R. Aslantas, B.S. Onder, G. Tozlu. First record of the invasive vinegar fly Drosophila suzukii (Matsumura) (Diptera: Drosophilidae) from eastern Turkey. Turk. J. of Zool., Vol. 40, 290-293, 2016. doi:10.3906/zoo-1412-25, 
2016.

[23] H.J. Burrack, J.P. Smith, D.G. Pfeiffer, G. Koeher, J. Laforest. Using volunteer-based networks to track Drosophila suzukii (Diptera: Drosophilidae) an invasive pest of fruit crops. J. of Integr. Pest Manage., Vol. 3, No. 4, B1-B5, 2012. doi: http://dx.doi.org/10.1603/IPM12012

[24] O. Rota-Stabelli, M. Blaxter, G. Anfora. Drosophila suzukii. Curr. Biol., Vol. 23, R8-R9, 2013. doi: 10.1016/j.cub.2012.11.021.

[25] Anonymous. Strategies to develop effective, innovative and practical approaches to protect major European fruit crops from pests and pathogens. http://dropsaproject.eu/ (accessed 29 February 2016), 2015

[26] C.M. Louise, G. Kuhl, M. Lopez-Ferber. Persistence of Botrytis cinerea in its vector Drosophila melanogaster. Phytopathol.. 934-939, $1996 . \quad$ https://www.apsnet.org/publications /phytopathology/backissues/Documents/1996Articles /Phyto86n09_934. PDF.

[27] J.A. Chandler, P. James, G. Jospin, J.M. Lang. The bacterial communities of Drosophila suzukii collected from undamaged cherries. Peer J., Vol. 474, 1-10, 2014. doi: $10.7717 /$ peerj. 474 .

[28] S. Siozios, A. Cestaro, R. Kaur, I. Pertot, O. Rota-Stabelli, G. Anfora. Draft genome of the Wolbachia endosymbiont of Drosophila suzukii. Genome Announcements, Vol. 1, No. 1, e00032-13, 2013. doi:10.1128/genomeA.00032-13.

[29] S. Tochen, D.T. Dalton, N.G. Wiman, C. Hamm, P.W. Shearer, V.M. Walton. Temperature-related development and population parameters for Drosophila suzukii (Diptera: Drosophilidae) on cherry and blueberry. Environ. Entomol., Vol. 43, No. 2, 501-510, 2014 https://doi.org/10.1603/EN13200

[30] T. Gokturk, E. Tozlu, R. Kotan. Investigation of prospects of entomopathogenic bacteria and fungi for biological control of Ricania simulans (Walker, 1851) (Hemiptera: Ricaniidae). Pak. J. of Zool., Vol. 50, 75-82, 2018. doi:http://dx.doi.org/10.17582/journal.pjz/2018.50.1.75.82.

[31] K. Sezen, Z. Demirbag. Bacterial isolates from Palomena prasina (Hemiptera: Melolontha, Coleoptera: Scarabaeidae). Ecol., Vol. 16, 34-40, 2007.

[32] D.C. Sands. Physiological criteria-determinate tests. In: Methods in Phytobacteriology. Z. Klement; K. Rhudolp and D.C. Sands (eds.). Academia Kiado, Budapest, Hungary, 1990.

[33] Z. Klement, K. Rudolph, D.C. Sands. Methods in Phytobact
https://www.amazon.com/Methods-Phytobacteriology-Z-K lement/dp/9630549557.

[34] J.P. Harley, L.M. Prescott. Laboratory Exercises in Microbiology. Fifth Edition, The McGraw-Hill Companies, New York, USA, 2002. http://www.justmed.eu/files/st/mi crobiologie/Microbiology $\% 20-\% 20$ Laboratory $\% 20$ Exercis es\%20\%5B5th\%20ed.\%20J.\%20P.\%20Harley\%20\&\%20L .\%20M.\%20Prescott\%5D.pdf.

[35] S. Ortucu. The isolation of entomopathogenic fungi to be used in biological control with two spotted spider mite $[($ Tetranychus urticae (Acari, Tetranychidae)] and the determination of their potentials as biopesticides. Atatürk University, PhD. Thesis, 144 p., 2012. https://tez.yok.gov.t r/UlusalTezMerkezi/tezSorguSonucYeni.jsp.

[36] J.A. Chandler, J.M. Lang, S. Bhatnagar, J.A. Eisen, A. Kopp. Bacterial communities of diverse Drosophila species: ecological context of a host-microbe model system. PLoS Genetics., Vol. 7, e1002272, 2011. doi:10.1371/journal.pgen.1002272.

[37] S.F. Altschul, W. Gish, W. Miller, E.W. Myers, D.J Lipman. Basic local alignment search tool. J. of Mol. Biol., Vol. 215, 403-410, 1990. http://dx.doi.org/10.1016/S00222836(05)80360-2

[38] K. Tamura, G. Stecher, D. Peterson, A. Filipski, S. Kumar. MEGA6: Molecular Evolutionary Genetics Analysis version 6.0. Mol. Biol. and Evol., Vol. 30, 2725-2729, 2013. doi: $10.1093 / \mathrm{molbev} / \mathrm{mst} 197$

[39] N. Saitou, M. Nei. The neighbor-joining method: A new method for reconstructing phylogenetic trees. Mol. Biol. and Evol., Vol. 4, 406-425, 1987. https://doi.org/10.1093/o xfordjournals.molbev.a040454.

[40] J. Felsenstein. Confidence limits on phylogenies: An approach using the bootstrap. Evol., Vol. 39, 783-791, 1985. doi: 10.1111/j.1558-5646.1985.tb00420.x.

[41] K. Tamura, M. Nei, S. Kumar. Prospects for inferring very large phylogenies by using the neighbor-joining method. Proceedings of the National Academy of Sciences (USA). Vol. 101, 11030-11035, 2004. https://doi.org/10.1073/pnas .0404206101

[42] M.I. Dunitz, P.M. James, G. Jospin, J.A. Eisen, D.A. Coil, J.A. Chandler. Draft genome sequence of Tatumella sp. strain UCD-D. suzukii (phylum Proteobacteria) isolated from Drosophila suzukii larvae. Genome Announcements, Vol. 2, e00349-14, 2014. doi: 10.1128/genomeA.00349-14

[43] N.A. Broderick, B. Lemaitre. Gut-associated microbes of Drosophila melanogaster. Gut Microbes, Vol. 3, No. 4, 307-321, 2012. Doi: 10.4161/gmic.19896. http://dx.doi.org /10.4161/gmic.19896.

[44] T. Brummel, A. Ching, L. Seroude, A.F. Simon, S. Benzer. Drosophila lifespan enhancement by exogenous bacteria. Proc. Natl. Acad. Sci., USA; Vol. 101, 12974-9; 2004. PMID: 15322271; http://dx.doi.org/10.1073/pnas.0405207 101.50 .

[45] C.R. Cox, M.S. Gilmore. Native microbial colonization of Drosophila melanogaster and its use as a model of Enterococcus faecalis pathogenesis. Infec. and Immun., Vol. 75, 1565-1566, 2007. doi:10.1128/IAI.01496-06.

iology. Akademiai Kiado, 547 p., 1990.

[46] F. Staubach, J.F. Baines, S. Kunzel, E.M. Bik, D.A. Petrov. Host species and environmental effects on bacterial communities associated with Drosophila in the laboratory and in the natural environment. PLoS ONE. www.plosone.org Vol. 8, No. 8, e70749, 2013. doi:10.1371/journal.pone.0070749.

[47] C.A.N. Wong, J.M. Chaston, A.E. Douglas. The inconstant gut microbiota of Drosophila species revealed by $16 \mathrm{~S}$ rRNA gene analysis. The ISME Journal, Vol. 7, 1922-1932, 2013. doi:10.1038/ismej.2013.86. doi: 10.1038/ismej.2013.86. 
42 Bacterial Communities of Drosophila suzukii (Matsumura, 1931) (Diptera: Drosophilidae) Damaged in Strawberry in Turkey

[48] M. Yaman, O. Erturk, I. Aslan. Isolation of Some Pathogenic Bacteria from The Great Spruce Bark Beetle, Dendroctonus micans and its Specific Predator,
Rhizophagus grandis. Folia Microbiol., Vol. 55, 35-38, 2010. doi: 10.1007/s12223-010-0006-9.

1 This study submitted as abstract in International DNA Day and Genome Congress (IDDGC), 24-28 April 2017, Ahi Evran University, Kırşehir, TURKEY. 